ARTICLE

https://doi.org/10.1057/s41599-020-0405-8

\title{
Institutional change and the limitations of consumer activism
}

\author{
Jacy Reese (iD) ${ }^{1 \times}$
}

\begin{abstract}
Organizations that aim to encourage or mitigate social change frequently face strategic trade-offs between changing the behaviour of individuals or institutions. This paper provides a conceptual analysis of this trade-off and an initial case study on the grand challenge of industrial animal agriculture. The nascent movement attempting to address this global issue has so far heavily focused on changing individual consumption with central messages like 'go vegan' and tactics like handing out pro-vegetarian leaflets. This paper critiques that focus, proposing instead what we call an institutional approach that focuses on changing governments, firms, social norms, and the like, particularly through developing and commercializing new food technologies. This paper argues from a perspective of effective altruism, aiming to maximize positive impact, that an increased use of the institutional approach may help organizations more effectively achieve their ethical goals. There are some cost-effective uses for the individual approach, so it should not be abandoned entirely, but a significant reduction may be prudent, at least in this context, and further research is warranted on this trade-off in other social contexts.
\end{abstract}

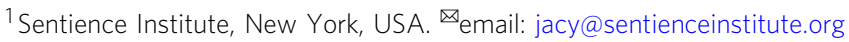




\section{Introduction}

onprofit organizations, mission-driven firms, politicians, and other social movement actors attempting to encourage or mitigate social change can do so through a variety of avenues (Armstrong and Bernstein, 2008). In practice, this frequently includes a trade-off between actions focused on individual behaviour or analogous actions focused on changing institutional behaviour. A digital security activist may decide between a strategy calling for consumers to use more secure passwords or calling for companies to require more secure passwords from their users. A gun safety organization can run classroom trainings in their local community or call for mandatory classroom trainings for all new gun owners. This paper provides a conceptual analysis of this trade-off, focused on the case study of the burgeoning movement aiming to mitigate or eliminate the harms of animal agriculture (hereafter, the 'farmed animal movement').

Ethicists have argued against animal agriculture, in particular factory farming (industrial animal agriculture intended to maximize output of meat and other animal products) from a variety of perspectives, most famously Peter Singer's utilitarian approach in Animal Liberation and Tom Regan's Kantian approach in The Case for Animal Rights. ${ }^{1}$ These scholars have variously framed the issue in terms of individual and collective obligations, but in practice, scholars and activists focused on farmed animals have largely converged on a heavy emphasis on individual consumption, mainly veganism but also vegetarianism, flexitarianism, furfree, cruelty-free, and other consumer labels and identities (Reese, 2018a, p. 114). For example, Mercy For Animals almost always ends their undercover investigation videos, which document the cruelty in animal agriculture, with consumption-centric calls to action such as, 'Leave animals off your plate' (MFA, 2019).

Since the mid-1990s, the farmed animal movement has also allocated a growing portion of their resources towards nonindividual-centric approaches. ${ }^{2}$ Most recently, tens of millions of dollars have been spent on 'cage-free' campaigns designed to persuade food retailers to no longer purchase eggs from farms that confine egg-laying hens in cages, which is widely regarded as one of the cruellest practices in the modern food system. Farmed animal social movement organizations (hereafter, 'organizations') have also sponsored 'meatless Monday' campaigns that seek to reduce total meat consumed at college cafeterias, workplaces, or other institutional settings. But the thrust of the movementespecially what the public views as the focus of farmed animal activism - has been individual consumer change.

Thus, this nascent social movement provides a promising case study for trade-offs of institutional and individual actions. This paper draws from a variety of qualitative and quantitative resources in a mixed methods approach à la Creswell (2009) to explicate an initial case for the institutional approach to social change. While there is a place for individual-focused activism in addressing the moral issues of animal agriculture, this paper argues that organizations' priorities should shift towards changing the practices of institutions such as governments and businesses, not individual consumers.

This paper makes an initial case for the institutional approach by cataloguing its potential benefits, drawbacks, and limitations as a strategy for social change. First, by any plausible metric, the individual approach has failed to achieve the large-scale gains that activists have sought. Second, in the face of analogous failures, other social movements have abandoned an individual focus in favour of an institutional one, making this a natural next step for the farmed animal movement. Third, the institutional approach leverages key motivators in human psychology, particularly moral outrage and social pressure, that the individual approach fails to utilize. Finally, certain innovations in food technology such as meat made without animals, successful corporate campaigns for farmed animal welfare, and poll results all provide direct evidence for the potential benefits of the institutional approach in the factory farming context.

\section{The institutional approach}

The first step in this sort of conceptual analysis is to establish definitions of the key terminology. An agreed-upon definition of institutions is 'a hard thing to pin down' (Mohr and Friedland, 2008). A precise definition is unnecessary here given the rather coarse grain of this analysis, which only contrasts institutions with individuals in society, but two useful definitions are 'an organization or other formal social structure that governs a field of action' (Rojas, 2013) and the refreshingly short 'a relatively self-contained social system' (Silverblatt, 2004). So these include governments, corporations, and NGOs as well as more diffuse entities such as family, property, and other collections of social norms that provide structure to social life. This paper also refers to the groups of people who populate formal institutions as institutions in themselves, such as U.S. residents who populate the U.S. as a country, and less formalized collections of people, such as the environmental movement. The institutional approach therefore focuses on changing the behaviour of these entities, such as if activists are able to prevent new stores from being opened by a retail chain (Ingram et al., 2010).

Our choice of definition here is analogous to Haslanger (2005)'s 'ameliorative approach' in which the purposes of relevant groups (e.g., social movement actors working to end industrial animal agriculture) are factored into the development of the concept. We use inductive and abductive methods, both of which have been used to study grand challenges-'specific critical barrier (s) that, if removed, would help solve an important societal problem with a high likelihood of global impact through widespread implementation'-similar to this context, to ensure that our theoretical development of the institutional approach incorporates the numerous relevant practical considerations highlighted in our case study (Eisenhardt et al., 2016; George et al., 2016; Augustine et al., 2019).

Thus, the institutional approach requires a shift from commonplace activist messaging in the farmed animal movement. The standard message, 'Go vegan', is typically targeted at individuals. A corresponding message within the institutional approach would be, 'End animal farming'. For organizations that favour a more moderate message, an individual-oriented message like, 'Eat less meat', could be changed to, 'Less meat in school cafeterias. ${ }^{3}$

The institutional approach also implies changing how activists invest their time. Popular grassroots tactics today include handing out leaflets and staging protests in restaurants and grocery stores to encourage individuals to change their diets. Institutional tactics include investing in 'cell-cultured meat' and trying to convince corporations to insist on higher welfare standards in their supply chain.

There is a wide spectrum here, given that most tactics have both individual and institutional characteristics. For example, an organization may run an institution-oriented campaign for cagefree eggs and also hope the discussion of animal cruelty will encourage some consumers to reduce egg consumption. Or, a documentary may be produced and distributed to the public with the intent of encouraging a wide variety of changes in society. These individual changes can effect or be prerequisites for institutional changes and vice versa. ${ }^{4}$ A single campaign, especially a large one, can utilize institutional and individual tactics for various aims. Tactics can also vary in whether they focus on the 
wellbeing of animals, either welfare or rights, or other issues of factory farming, such as environmental and human health effects, though animal wellbeing (welfare, rights, or otherwise) has been the primary activist focus to date and thus is my focus here.

The arguments herein are grounded in the ideas of effective altruism, a community of scholars and activists addressing the goal of maximizing one's positive impact on the world (Reese, 2018a, p. xiii). For example, among effective altruists who care about animals, there has been a focus on the plight of farmed animals because they make up the vast majority of domestic animals, despite being less salient in everyday human life than other animals like cats and dogs. Effective altruism provides a framework for addressing the increasing demands for empirically focused, intellectually rigorous research on animal advocacy, including the wellbeing of wild animals (Smith and Reese, 2016; Reese, 2018b). In other contexts, effective altruism proponents such as Peter Singer have set up organizations such as The Life You Can Save to evaluate the most cost-effective ways to increase human welfare (Singer, 2015). Thus the current research addresses the question, 'How can social movements navigate the trade-off between individual and institutional tactics to most effectively achieve their goals?'

An important distinction to draw is that between institutional change and the 'systemic change' approach often discussed within the field of effective altruism (Snow, 2015; Gabriel, 2017). Systemic change typically refers to either fixing an issue at a deeper level further down the causal chain, such as addressing the causes of poverty rather than directly alleviating the suffering of people in poverty, or it refers to fundamental transformations of society, such as the end of capitalism, that would affect a wide range of social issues (Berkey, 2018; Broi, 2019; Dietz, 2019; Kissel, 2017). The institutional distinction might be a more fundamental or systemic change than individual change, but the relationship between the two axes is unclear because both individuals and institutions can effect changes and be changed at superficial or fundamental levels.

Institutional change can be undertaken from a variety of ideological perspectives. For example, if one is an anti-capitalist, then one may seek to not just end industrial animal agriculture, but to ensure it is not replaced with a comparable market system. This may even require metaformative steps prior to work on any specific manifestation of capitalism, whether the food system, transportation, energy, or other morally pertinent sectors. On the other hand, from a pro-capitalist perspective, one may be particularly eager to displace industrial animal agriculture via market forces, such as encouraging large food companies to embrace and develop high-quality, affordable animal-free food technology.

Finally, this paper treats the individual-institutional axis as correlated with but separate from other common distinctions between movement strategies, such as whether the focus is on improving the lives of animals (welfare), reducing the number of animals being used (reduction), or maximizing the likelihood that no animals are used at some point in the future (abolition).

\section{The failure of the individual approach}

Now that we have laid out the theory of the institutional approach, we must take stock of the current state of affairs in the context of the farmed animal movement. Activists have spent decades calling for individuals to change their diets, yet there has been little corresponding change. Per capita meat consumption is at its highest level ever in the U.S., despite a brief dip a few years ago (Ritchie and Roser, 2017). Worse, the trend seems to be toward increased chicken consumption, which consumers perceive as healthier than beef and pork. Due to the relative size (i.e., calories per animal) and the severity of the welfare problems in chicken production, this means it is likely that there is more farmed animal suffering than ever.

It is easy to assume that the increased variety of plant-based alternatives such as veggie burgers and nut-based cheeses at restaurants and grocery stores indicates that the number of vegetarians and vegans is increasing. However, the Vegetarian Resource Group has conducted semi-regular polls on whether people 'never eat' a variety of foods including animal products. There was an uptick following 1997, when $1 \%$ of US adults were vegetarians, but the figure has held around 3-5\% since 2009 with vegans accounting for around half that number (VRG, 2019).

Even if this increase occurred due to vegan activism, that is not much progress in 22 years. Additionally, in-depth consumer survey data suggests that only a small fraction of self-identified vegetarians and vegans actually avoid all meat or animal products, respectively, and there is some evidence that the majority of people who become vegans eventually abandon the diet (Faunalytics, 2014). So, while there might be more interest in plant-based eating, it is not having anywhere near the effect for which activists have hoped.

Why is the individual approach failing? There are many potential reasons. Most obviously, animal products are ubiquitous, culturally significant, tasty, and relatively inexpensive. Moral arguments seem to lack sufficient power to address this combination of motivational factors. There are a variety of economic and political structures that benefit from the status quo of factory farming and thus seek to resist change (Nibert, 2013). Social movements that require morality to trump self-interest may eventually succeed, but they face an uphill battle.

\section{Historical social movements}

Whether an individual or institutional approach is most effective hinges on the specific context of the social movement, some of which may necessitate a specific approach. For example, the movement against the death penalty would not be able to achieve success via individual consumer change because the death penalty does not require specific consumer choices.

Nonetheless, there is a prima facie unclear and important trade-off in many contexts. Relatively few social movements have focused heavily on individual consumption. The main potential examples are public health campaigns, such as tobacco control, obesity reduction, and healthy eating. These campaigns have almost necessarily focused on changing individuals because the primary motivations behind the changes have been improving personal health. Someone who stops smoking primarily benefits their own life, such as by reducing the likelihood of developing lung cancer, though of course there are secondary impacts like second-hand smoke or the influence on children who are more likely to smoke if a parent does (Vuolo and Staff, 2013). Farmed animal activism is instead centred on the motivation of helping animals or the environment, and it can either take an individual approach (e.g., convincing people one by one to change diets) or an institutional approach (e.g., banning animal agriculture, an effort that may be opposed by consumers but could nonetheless be implemented via institutional changes).

There are two more interesting cases of social movements focusing on individual change. First, much environmental discussion focuses on personal consumption changes, including recycling, purchasing eco-friendly appliances, abstinence from high-emission activities such as flying and eating red meat, and abstinence from everyday uses of plastic, such as plastic cutlery and straws at restaurants. However, environmentalists have recently railed against this approach, condemning it as 'green consumerism' and calling for what they have seen to be a more 
effective tactic: institutional change, particularly government regulation and taxation of private industry (Monbiot, 2009).

The second case is the free produce movement (FPM), a submovement of 18th and 19th century abolitionists who advocated abstinence from slave-made products (Crothers, 2006). This approach is analogous to veganism, as FPM activists believed consumers of slave-made products were individually culpable for the atrocity of slavery. Abolitionist leader William Lloyd Garrison said in 1831, '[E]ntire abstinence from the products of slavery is the duty of every individual. In no other way can our example or influence be exerted so beneficially'. However, by the late 1840s, these same activists called for a switch to other approaches. Garrison himself wrote in 1847 that he had 'erred in judgement' by focusing on FPM, and that it was 'wasting time'. He presciently suggested that a focus on abstinence might have a moral licensing effect, saying that abstinence 'furnishes [abstainers] with a pretext to do nothing more for the slave, because they do so much'. In fact, he made the seemingly radical claim that abolitionists are in fact the only ones who can 'innocently use' slave-made goods (The Non-slaveholder, 1847).

The British antislavery movement does provide one example of the way activists can make use of individual tactics in a broader institutional campaign. In 1791, when the House of Commons voted 163-88 against the gradual abolition of the transatlantic slave trade, activists boycotted sugar from the Americas. Approximately 4-6\% of the British population participated, and it may have contributed to the 1792 passage of gradual abolition in the House of Commons. The instrumental, short-term, and single-product features of this boycott may have made it more effective than the FPM in the following decades (Witwicki, 2017).

\section{Social psychology}

In addition to the historical evidence, social psychologists have identified certain behavioural motivators that may act as crucial levers in large-scale social change. Social movement track records provide evidence of the success of activism tactics at making progress in the inherently collective, intertwined fabric of human society. Evidence from social psychology and other experimental fields lack this holistic quality, but given the ability to rigorously test individual behaviour with high sample sizes and isolation of variables, behavioural evidence can tease out the role of certain important motivators.

Anger has been cited as a key emotional motivator for activists and a key factor in encouraging people to break from system justification (Wakslak et al., 2007; Klandermans et al., 2008). Moral outrage is that feeling of anger, or outrage, applied to a moral context. Goodenough (1997) argues that moral outrage 'can be understood as the human expression of what we perceive as territorial behaviour in animals'. Moreover, it is 'a response to the behaviour of others, never one's own'. Given the moral arguments that undergird social movements-especially movements like farmed animal activism wherein the activists are distinct from the oppressed population and therefore usually need motivation beyond self-interest-it seems reasonable to expect much of the anger felt by activists is classifiable as moral outrage.

Consider that individual rhetoric centres consumers of animal products-who make up over $99 \%$ of the population-as the enemy (Faunalytics, 2014). Calling for individual change implies that the consumer is doing wrong. This implication is rarely lost on the audience of farmed animal activism. In many contexts, from social media to street activism to lobbying politicians, the most common reaction to farmed animal activism is defensiveness, perhaps because the audience feels accused of wrongdoing.

Consider other movements that address issues with limited public participation, such as Black Lives Matter (BLM). In this movement, the public discourse has emphasized videotaped instances of police brutality, and police officers who engage in egregious behaviour are seen as the enemy. The most common and likely response among the audience of BLM activism is to experience moral outrage, often visceral, at the culprit (Carney, 2016).

Consider also the case of human rights movements that address issues that involve widespread public participation, such as fair-trade activists targeting sweatshops. Given the public participation element, issues pertaining to abuses of labourers are more closely related to the widespread issues of animal exploitation than those pertaining to acts of violence perpetrated by police officers. Fair trade activism tends to portray the enemy as corporations that own sweatshops or purchase products made inside them. They do this rather than targeting the end consumers of sweatshop-made products, which has been correlated with their success (Bartley and Child, 2014).

Thus, rhetoric against animal exploitation institutions-corporations, industries, governments, other organizations, or society as a whole-could spark more moral outrage by placing the blame or guilt on those institutions rather than on the individual.

In addition to moral outrage, there is ample experimental evidence that peer pressure strongly motivates behaviour across areas of life including teenage drug use, music preferences, and household energy use (Asch, 1956; Hansen and Graham, 1991; Salganik et al., 2006; Schultz et al., 2007). Social pressure, from both authorities and peers, has been implicated in a variety of historical tragedies such as the Salem Witch Trials and the Holocaust.

However, activists can utilize social pressure for good. One example is the common practice of activists targeting fans of celebrities with Facebook advertisements that tell them the celebrity is vegetarian (Reese, 2016). Activists can even snowball participation in events by advertising them as having large numbers of participants in a self-fulfilling prophecy where the apparent popularity of the event leads to actual popularity (Reese, 2018a, p. 96).

The final motivator this paper considers, moral licensing, is 'the effect that when people initially behave in a moral way, they are later more likely to display behaviours that are immoral, unethical, or otherwise problematic' (Blanken et al., 2015). It has the opposite effect of moral consistency, when initial moral behaviour increases the likelihood of future moral behaviour. Both of these effects have been documented in experimental research (Mullen and Monin, 2016).

One of the main areas in which moral licensing is thought to occur is environmental behaviour (Tiefenbeck et al., 2013). Moral licensing is often considered a negative effect of 'green consumerism' (Sachdeva et al., 2015). Consider, for example, a consumer who purchases eco-friendly, energy-efficient lightbulbs. Then, consciously or otherwise, that consumer could feel more justified in undertaking a different behaviour that is thought to negatively impact the environment, such as eating a steak. This can allow the consumer to feel less guilt than they otherwise would when engaging in that negative behaviour.

Moral licensing could pose a similar challenge for farmed animal activism. However, there is little reason a priori to expect licensing over consistency in these situations because no clear trends have been shown in the literature. Indeed most animal activists themselves began taking small actions for animals before scaling up their involvement. So overall, the considerations of moral licensing and moral consistency do not seem to be compelling evidence for either the institutional or individual approach.

In addition to these three motivators, activists should consider common psychological reactions to farmed animal messaging. One might object that individual approaches offer more clarity in the ask of their messaging; there is little room for the audience to 
wonder what the activist wants of them. If the individual message is, 'Go vegan', then that is also an explicit call to action. 'Leave animals off your plate' can require a bit of digestion to understand that the ask is for a vegetarian diet, but it is still relatively understandable. However, while this is an upside of the individual approach, institutional messaging can also include a clear call to action.

\section{Animal farming attitudes}

The evidence considered so far is mostly from contexts other than farmed animal activism. What direct evidence can be gleaned? We cannot look at long-term social movement outcomes for farmed animal activism since the movement seems to still be in an early stage so we cannot yet know the outcomes, and few experiments have been done on even individual reactions to farmed animal messaging. Nonetheless, we can leverage certain data to help estimate the efficacy of the individual and the institutional approach.

Public opinion is one available piece of evidence. There is remarkably high public support for institutional change. Over $70 \%$ of Americans support various welfare policies, such as cagefree eggs, slower-growth chicken genetics (chickens raised for meat grow so fast they cannot walk properly (Kestin et al., 1992)), higher-welfare slaughter methods, and an end to extreme crowding (MFA, 2017). Ballot measures in various U.S. states for welfare laws consistently get majority votes, including an astonishing 78\% approval for Massachusetts' 2016 cage-free law (HSUS, 2016).

Although data is limited, there is also surprisingly large support even for radical policy change to animal agriculture. For example, $47 \%$ of U.S. adults supporting a ban on slaughterhouses and $32 \%$ believing 'animals deserve the exact same rights as people to be free from harm and exploitation' (Riffkin, 2015; Reese, 2017). Effecting real-world institutional change is much more difficult than achieving poll results, but this still constitutes evidence for the relative tractability of institutional change, given fewer than $1 \%$ of U.S. adults follow a vegan diet (Faunalytics, 2014).

Prior to conducting the poll on banning slaughterhouses, the researchers informally surveyed a variety of farmed animal activists and scholars on their expectations of the results. Most respondents reasoned based first on the number of vegetarians, $\sim 6 \%$, then accounting for the fact that some vegetarians do not want to impose their vegetarianism on society as a whole, and the fact that survey results tend to usually be a little close to 50-50 than expected because some respondents do not read the questions thoroughly. Few activists or scholars expected results above $20 \%$. The remarkable survey finding of $47 \%$ surprised everyone involved in the research. It was also confirmed in a replication of the survey by a different group of researchers who did not believe the original results (Norwood and Murray, 2018).

If we take all this survey data into account, institutional change might be able to garner much wider support and participation than individual change. This individual-institutional gap seems to be an underexplored research topic in the context of what makes social movements succeed. This gap may result from a rational consideration of how behaviour change is easier to adopt en masse with institutional support (e.g., if everyone in a city is vegetarian, then consumers will not have to search for vegetarian food options), or it may result from a difference in gut reaction to proposals of individual change versus institutional change (e.g., people might think of their own diet changing when a vegetarian diet is proposed, but think of other people's diets changing when a ban on slaughterhouses is proposed).

Supporting institutional change even when one will not take individual action can make sense from the consumer perspective.
Changing your diet while everyone around you maintains the status quo can be quite difficult both materially, such as struggling to find tasty vegan options at restaurants, and socially, having a diet that strikes your peers as weird or unusual. However, if everyone makes the change together, the material and social contexts become much easier to navigate, such as if animalfree foods become more accessible in restaurants and grocery stores. It is unclear to what extent these rational factors contribute to the individual-institutional gap relative to other less-rational factors, such as framing effects where voters or survey respondents may fail to consider the implications of an institutional change for their personal behaviour. These questions seem like a fruitful tract for future research.

\section{Potential of technology}

The final piece of evidence we must consider to evaluate the institutional approach is the influence of technology on the potential for social change. If humans were entirely driven by morality, animal activists would need only to expose the facts of animal sentience and animal suffering to have consumers swap out their cheeseburger for beans and rice. In this scenario, the individual approach-particularly one-by-one education-would hold much more promise. But in the real world, people also need assistance in overcoming weakness of will. The moral step of veganism or vegetarianism becomes far easier if one can swap out an animal-based beef burger for an Impossible Burger, a new food product made from wheat, potato, and other plant ingredients to mimic the culinary experience of the All-American beef burger (IF, 2018). And with the prospect of cost-competitive cell-cultured meat, real meat made with animal cells instead of a whole animal, swapping out conventional animal products may become far easier.

The usefulness of these technologies becomes even clearer when we consider the sheer inefficiency of animal agriculture. Animals are living beings who do not just produce meat and other animal products. They walk around, maintain homoeostasis, and grow hair, beaks, bones, and brains. Because of these processes, animal farming requires at least 10 plant-based calories for every calorie of meat and at least $5 \mathrm{~g}$ of plant-based protein for every gram of animal-based protein (AWFW, 2015). Animal-free food technology bypasses the middleman and produces the end product directly. Because humans have an incentive towards efficiency rooted in their own self-interest-more output for less input-food technology is a powerful institutional approach.

If these technologies continue to grow in popularity, displacing conventional meat, dairy, and egg products, then the farmed animal movement and society as a whole will need to contend with a variety of ethical considerations. For example, major food companies Tyson Foods and Cargill have already invested in Beyond Meat and Memphis Meats, respectively (Reese, 2018a, pp. 54-90). These investments could spur innovation and increase market share, but if these large companies acquire sufficient control, then they may also have the ability to quash the technologies if they are seen as competing with the conventional industry, as well as the ability to derail the ethical potential of these technologies, such as by producing them with unsustainable or unethical methods.

The rest of this paper considers a variety of supplementary ethical considerations that bear on the strategic value of the institutional and individual approaches.

\section{Welfarism and abolitionism}

Wyckoff (2014) draws a distinction between three ethical perspectives: welfarists, who 'reject the radical exceptionalists' claim that we owe no direct duties to animals, but maintain that the moral status of animals does not preclude our treating them as 
the resources of human beings, as long as the animals are not made to suffer unnecessarily', and abolitionists, who argue 'nonhuman animals have a moral status that is incompatible with the use of animals as the resources of human beings, and that animal use must be abolished either as a matter of right or as a matter of justice', of which there are two types, practical and radical, depending on whether they 'are amenable to short-term reforms that leave intact the basic structure of the resource paradigm'.

Welfarists and practical abolitionists both seek the end of factory farming. Practical abolitionists also seek the end of other forms of animal agriculture. Both of these goals fit neatly into the institutional approach, though specific manifestations might vary, such as messaging of 'end factory farming' versus 'end animal farming..

Radical abolitionists may take issue with the institutional approach if they believe that most tractable institutional campaigns 'leave intact the basic structure of the resource paradigm'. However, many animal activists would contend that even the most moderate of welfare reforms, such as increasing cage sizes, threaten the resource paradigm to some extent because they add weight to the moral valuation of animals in society.

Even with this type of strict restriction, radical abolitionists are still free to use institutional tactics and messaging that directly aim for the abolition of animal use, such as centring a message of 'End animal farming'. However, in this case, they might believe that focusing entirely on abolition leaves too much ground to cover in the meantime, and that veganism is the only viable midway goal, in which case a radical abolitionist would lean towards the individual approach.

\section{Individualism centres the consumer}

There are a variety of actions one can take to help animals, but veganism and other diet choices (e.g., vegetarian, flexitarian, pescatarian) are unique in that they imbue a strict behavioural identity or label onto the individual. These identities come with a variety of downsides, such as potential ostracization, but also upsides, such as a sense of moral cleanliness, superiority, or even being holier-than-thou. In fact, in 19th century America, vegetarianism was largely seen as a way to rid oneself of immoral tendencies and indulgences (JBLCA, 2018).

In this way, the topic of conversation when using the individual approach tends to drift towards the individual, becoming a matter of personal preferences, beliefs, needs, wants, values, or other attributes. This obfuscates the moral imperative against animal suffering and exploitation. It also risks an unrealistic expectation of dietary purity, given that even the strictest vegans struggle to eliminate $100 \%$ of their contribution to animal exploitation due to issues such as animals killed in plant agriculture, tiny amounts of contamination from animal products, or consuming goods from retailers or food companies that serve animal products.

By contrast, the institutional approach centres the animals, or at least the systems that perpetuate animal suffering and exploitation, rather than human do-gooders. It also emphasizes the social, collective, and political nature of animal ethics, reflecting the so-called 'political turn in animal ethics' (Garner, 2016).

Given that animal activists aim to raise the moral status of animals, to help animals, or to do what is right by the animals themselves, veganism and individual consumption can be a wayward turn away from what will most help animals and towards personal purity and self-congratulation.

\section{The ethical issue of factory farming demands more than nonparticipation}

Consumer change does reduce suffering and exploitation. While every unit of animal product not purchased does not always lead to one fewer unit produced, there is still a nonzero expected value, adjusted for by economic elasticity (Norcross, 2004; Tomasik, 2006).

But this is only a nonparticipation effect (i.e., doing good by not committing a harmful action), rather than doing good beyond what would happen if one had never come into existence. Institutional actions, on the other hand, such as campaigning for an ethical food system or simply signing a petition for cage-free eggs, does good that would not otherwise occur according to the values of the farmed animal movement.

There are over 100 billion farmed animals in existence today (Witwicki, 2019). If one accepts animals as sentient beings, or otherwise as moral patients (Regan, 1983), then the case is fairly straightforward from the farmed animal movement's perspective that animal farming being a moral catastrophe, perhaps even comparable to humane slavery and genocide. In such cases, there seems to be not just a moral demand for nonparticipation in the farmed animal movement, but for active opposition to the moral catastrophe.

\section{Individualism may be a manifestation of speciesism}

Why is it so easy to blame issues of animal exploitation on consumer choice? As discussed previously, consumer focus is rare in human rights movements, and the lack of impetus for institutional change in the case of animal rights might be partly due to speciesism (Singer, 2009). This is plausible given evidence that speciesism exists as not just a philosophical concept but also as a psychological construct, namely 'the assignment of different moral worth based on species membership' (Caviola et al., 2018). Despite their goals, activists themselves may still harbour speciesism, and perhaps should expect to harbour much of it given the ubiquity of bias and prejudice in human society. Similar prejudices against humans, such as humans in faraway locations, might also contribute to a default focus on consumption in issues like sweatshops and other exploitative labour institutions.

The grounding of individual in the prejudice of speciesism is most apparent in that a focus on personal consumption is the favoured framing of factory farmers and meat companies, which tend to emphasize that vegetarianism is a personal choice to be respected, as is omnivory. If animal issues can be reduced to personal choice, then the ideological battle is in some sense already lost by animal activists. Survey data suggests a full $97.5 \%$ of Americans agree with the statement, 'Whether to eat animals or be vegetarian is a personal choice, and nobody has the right to tell me which one they think I should do' (Reese, 2017).

\section{Concluding remarks}

This paper has argued on the basis of empirical and ethical considerations that animal activists should shift some resources from the predominant individual approach to an institutional approach. This shift does not mean forsaking individual change altogether. ${ }^{6}$ For example, in the call to action of an overall institutional-leaning message, such as, 'End factory farming', one can discuss individual diet change as one possible action to take, though in some cases activists might prioritize a different call to action, such as supporting a current policy campaign. Similarly, if one is working to change an institution such as a company or government, boycotts can be an important tool in the activist toolbelt to pressure the institution into changing, at least if they are framed as a symbolic action in the service of that targeted goal rather than as a personal choice. Most large-scale activist campaigns and roadmaps incorporate both individual and institutional tactics.

There are a variety of methods that future research could use to analyse the intersecting effects of institutional and individual approaches on social change. One approach is a quantitative 
model of social agents interacting with pressure from the environment, such as in the context of Hydrogen Fuel Cell Vehicles in the UK transport sector (Köhler et al., 2009). These methods may be able to capture the nuance of social systems via qualities such as 'complexity', 'complicatedness', and 'wickedness' (Andersson et al., 2014; Andersson and Törnberg, 2018) as well as nuance of individual decision-making via qualities, such as 'uncertainty' and 'cognitive effort', the consideration of incentives in predicting behaviour change, and the modelling of social practice generation based in consumer behaviour (Jager and Janssen, 2003; Ferrara et al., 2012; Holtz, 2014). There is also work on agent-based models of near-Zero Energy Buildings in the Netherlands housing sector (Rosales-Carreón and García-Díaz, 2015) and agent-based models of communication networks in the adoption of solar photovoltaics (Henry and Brugger, 2017). Given this plethora of factors in social change and methods to study them, it may be useful to incorporate these in further mixed methods work analysing the individual-institutional trade-off.

Importantly, changing an institution is distinct from, and can be done entirely without, changing individual consumption choices. For example, one-on-one persuasion could convince the CEO of a company to change the company's use of animal products, but this persuasion does not need to address whether the $\mathrm{CEO}$ chooses to eat meat. In fact, given the CEO's power over their company, it might be unwise to distract them with the relatively small benefit that would come from changing their diet.

Given there are currently over 100 billion animals in the global food system, and over $90 \%$ of them endure intensive farming methods, these considerations of effective animal advocacy are exigent (Witwicki, 2019). Moreover, the moral outrage against factory farming, the growing legislative momentum for animal policy change, and the inchoate industry of animal-free food technologies including cell-cultured meat suggest that humanity could be at an inflection point in farmed animal activism. If stakeholders navigate this time period with careful research and strategic analysis, this could be the cusp of unprecedented success for the farmed animal movement. Moreover, other efforts to change society may benefit from further consideration of the institutional approach, and more research is warranted to anatomize the individual-institutional trade-off in other contexts of activism, business, and technology.

Received: 5 October 2019; Accepted: 3 February 2020;

Published online: 12 February 2020

\section{Notes}

1 Scholars and activists sometimes frame the issue as factory farming, industrial animal agriculture, excess animal agriculture beyond that which would provide some moderate amount of animal products in the human diet, all animal agriculture, or all animal use in any industry (cosmetics, scientific research, fur, etc.). The argument for the institutional approach can be made in any of these contexts, and for the sake of simplicity, this paper uses 'farmed animal' as the general term to refer to actors seeking to address the ethical issues they see with at least some forms of animal agriculture.

2 The full reasons for this transition are beyond the scope of this article, but it seems to be caused by the growing amount of evidence for the institutional approach and the dissemination of that evidence to movement leaders by groups like Animal Charity Evaluators, the Open Philanthropy Project, and Sentience Institute.

3 These are each short messages, and sometimes activists have opportunities to communicate at length, such as in a one-on-one conversation or in the several pages of text in a leaflet. In long-form, messaging also face the trade-off of individual and institutional messaging, though they can also include multiple comments and suggestions for their audience.

4 Any dependence of individual and institutional changes on each other does not preclude one approach being more effective than the other on the margin. For example, if a small amount of individual change makes institutional change possible, but at least that amount is produced organically without the intervention of deliberate social movement actors, then this is not a reason to favour the individual approach. Activists should of course consider dependencies and act accordingly. See also Carberry et al. (2019) on the potential interconnectedness of activists, organizational fields, and corporate managers.

5 There are empirical arguments for each of these messages that do not depend on philosophical position. For example, practical abolitionists might campaign to 'end factory farming' if they want to rally support from mainstream politicians, while welfarists might campaign to 'end animal farming' if they favour clarity in messaging and believe ending factory farming alone is an impractical or at least insufficiently motivational goal.

6 The best guess of the authors-if required to quantify their view-is that the messaging of animal activists is currently around $90 \%$ individual and $10 \%$ institutional, and that the ideal allocation would be around 30\% individual and $70 \%$ institutional.

\section{References}

Andersson C, Törnberg A, Törnberg P (2014) Societal systems-complex or worse? Futures 63:145-157. https://doi.org/10.1016/j.futures.2014.07.003

Andersson C, Törnberg P (2018) Wickedness and the anatomy of complexity. Futures 95:118-138. https://doi.org/10.1016/j.futures.2017.11.001

Armstrong EA, Bernstein M (2008) Culture, power, and institutions: a multiinstitutional politics approach to social movements. Sociol Theory 26:74-99. https://doi.org/10.1111/j.1467-9558.2008.00319.x

Asch SE (1956) Studies of independence and conformity: I. A minority of one against a unanimous majority. Psychol Monogr: Gen Appl 70:1-70. https:// doi.org/10.1037/h0093718

Augustine G, Soderstrom S, Milner D, Weber K (2019) Constructing adistant future: imaginaries in geoengineering. Acad Manag J 62:1930-1960. https:// doi.org/10.5465/amj.2018.0059

AWFW (2015) Feed: meat ratios. A Well-Fed World. https://awfw.org/feed-ratios/. Accessed 22 Feb 2019

Bartley T, Child C (2014) Shaming the corporation: the social production of targets and the anti-sweatshop movement. Am Sociol Rev 79:653-679. https://doi. org/10.1177/0003122414540653

Berkey B (2018) The institutional critique of effective altruism. Utilitas 30:143-171. https://doi.org/10.1017/S0953820817000176

Blanken I, van de Ven N, Zeelenberg M (2015) A meta-analytic review of moral licensing. Pers Soc Psychol Bull 41:540-558. https://doi.org/10.1177/ 0146167215572134

Broi A (2019) Effective altruism and systemic change. Utilitas 1-15. https://doi.org/ $10.1017 /$ S0953820819000153

Carberry EJ, Bharati P, Levy DL, Chaudhury A (2019) Social movements as catalysts for corporate social innovation: environmental activism and the adoption of green information systems. Bus Soc 58:1083-1127. https://doi. org/10.1177/0007650317701674

Carney N (2016) All lives matter, but so does race: Black Lives Matter and the evolving role of social media. Humanit Soc 40:180-199

Caviola L, Everett JAC, Faber NS (2018) The moral standing of animals: towards a psychology of speciesism. J Pers Soc Psychol. https://doi.org/10.1037/pspp0000182

Creswell JW (2009) Research design: qualitative, quantitative, and mixed methods approaches, 3rd edn. Sage Publications, Thousand Oaks

Crothers AG (2006) Free produce movement. In: Hinks PP, McKivigan JR (eds) Encyclopedia of antislavery and abolition. Greenwood Press, Westport

Dietz A (2019) Effective altruism and collective obligations. Utilitas 31:106-115 https://doi.org/10.1017/S0953820818000158

Eisenhardt KM, Graebner ME, Sonenshein S (2016) Grand challenges and inductive methods: rigor without rigor mortis. Acad Manag J 59:1113-1123. https://doi.org/10.5465/amj.2016.4004

Faunalytics (2014) Study of current and former vegetarians and vegans. Faunalytics. https://faunalytics.org/study-of-current-and-former-vegetarians-and-vegans/. Accessed 22 Feb 2019

Ferrara EL, Chong A, Duryea S (2012) Soap operas and fertility: evidence from Brazil. Am Econ J 4:1-31. https://doi.org/10.1257/app.4.4.1

Gabriel I (2017) Effective altruism and its critics. J Appl Philos 34:457-473. https:// doi.org/10.1111/japp. 12176

Garner R (ed) (2016) The political turn in animal ethics. Rowman \& Littlefield International, Lanham

George G, Howard-Grenville J, Joshi A, Tihanyi L (2016) Understanding and tackling societal grand challenges through management research. Acad Manag J 59:1880-1895. https://doi.org/10.5465/amj.2016.4007

Goodenough WH (1997) Moral Outrage: Territoriality in Human Guise. Zygon ${ }^{\circledR}$ 32(1):5-27

Hansen WB, Graham JW (1991) Preventing alcohol, marijuana, and cigarette use among adolescents: peer pressure resistance training versus establishing conservative norms. Prev Med 20:414-430

Haslanger S (2005) What are we talking about? The semantics and politics of social kinds. Hypatia 20:10-26. https://doi.org/10.1111/j.1527-2001.2005.tb00533.x 
Henry AD, Brugger HI (2017) Agent-based explorations of environmental consumption in segregated networks. In: García-Díaz C, Olaya C (eds) Social systems engineering. John Wiley \& Sons, Ltd, Chichester, UK, pp. 197-214

Holtz G (2014) Generating social practices. J Artif Soc Soc Simul 17. https:/doi. org/10.18564/jasss.2333

HSUS (2016) Initiative and referendum history-animal protection issues. Humane Society of the United States. https://www.humanesociety.org/sites/ default/files/docs/ballot-initiatives-chart.pdf. Accessed 22 Feb 2019

IF (2018) Impossible burger. Impossible Foods. https://impossiblefoods.com/food/. Accessed 22 Feb 2019

Ingram PL, Yue L, Rao H (2010) Trouble in store: probes, protests, and store openings by Wal-Mart, 1998-2007. Social Science Research Network, Rochester, NY

Jager W, Janssen M (2003) The need for and development of behaviourally realistic agents. In: Simão Sichman J, Bousquet F, Davidsson P (eds) Multi-agentbased simulation II. Springer, Berlin, Heidelberg, pp. 36-49

JBLCA (2018) Diet reform and vegetarianism. Janice Bluestein Longone Culinary Archive. https://www.lib.umich.edu/janice-bluestein-longone-culinary-archive/ diet-reform-and-vegetarianism. Accessed $22 \mathrm{Feb} 2019$

Kestin SC, Knowles TG, Tinch AE, Gregory NG (1992) Prevalence of leg weakness in broiler chickens and its relationship with genotype. Vet Rec 131:190-194

Kissel J (2017) Effective altruism and anti-capitalism: an attempt at reconciliation. Essays Philos 18. https://doi.org/10.7710/1526-0569.1573

Klandermans B, van der Toorn J, van Stekelenburg J (2008) Embeddedness and identity: how immigrants turn grievances into action. Am Sociol Rev 73:992-1012. https://doi.org/10.1177/000312240807300606

Köhler J, Whitmarsh L, Nykvist B et al. (2009) A transitions model for sustainable mobility. Ecol Econ 68:2985-2995. https://doi.org/10.1016/j.ecolecon.2009.06.027

MFA (2019) Undercover investigations. Mercy for Animals. https://mercyforanimals. org/investigations. Accessed 22 Feb 2019

MFA (2017) Four out of five Americans want restaurants and grocers to end cruel factory farming practices. PR Newswire. https://www.prnewswire.com/newsreleases/four-out-of-five-americans-want-restaurants-and-grocers-to-endcruel-factory-farming-practices-300487484.html. Accessed 22 Feb 2019

Mohr JW, Friedland R (2008) Theorizing the institution: foundations, duality, and data. Theor Soc 37:421-426. https://doi.org/10.1007/s11186-008-9071-3

Monbiot G (2009) We cannot change the world by changing our buying habits. The Guardian

Mullen E, Monin B (2016) Consistency versus licensing effects of past moral behavior. Annu Rev Psychol 67:363-385. https://doi.org/10.1146/annurevpsych-010213-115120

Nibert DA (2013) Animal oppression and human violence: domesecration, capitalism, and global conflict. Columbia University Press, New York

Norcross A (2004) Puppies, pigs, and people: eating meat and marginal cases. Philos Perspect 18:229-245. https://doi.org/10.1111/j.1520-8583.2004.00027.x

Norwood B, Murray S (2018) FooDS Food Demand Survey, vol. 5. Oklahoma State University. http://agecon.okstate.edu/files/january\%202018.pdf

Reese J (2018a) The end of animal farming: how scientists, entrepreneurs, and activists are building an animal-free food system. Beacon Press, Boston

Reese J (2018b) Maladies, Blessures, Faim... Les Animaux Sauvages Souffrent. Nous Devrions Les Aider. Les Cahiers antispécistes

Reese J (2016) Our initial thoughts on the mercy for animals facebook ads study. Animal Charity Evaluators. https://animalcharityevaluators.org/blog/ourinitial-thoughts-on-the-mfa-facebook-ads-study/. Accessed 22 Feb 2019

Reese J (2017) Survey of US attitudes towards animal farming and animal-free food October 2017. Sentience Institute. http://www.sentienceinstitute.org/animalfarming-attitudes-survey-2017. Accessed 22 Feb 2019

Regan T (1983) The case for animal rights. University of California Press, Berkeley

Riffkin R (2015) In U.S., more say animals should have same rights as people. Gallup. https://news.gallup.com/poll/183275/say-animals-rights-people.aspx. Accessed 22 Feb 2019

Ritchie H, Roser M (2017) Meat and seafood production \& consumption. Our World in Data

Rojas F (2013) Institutions-sociology. Oxford Bibliographies. http://www. oxfordbibliographies.com/view/document/obo-9780199756384/obo9780199756384-0132.xml. Accessed 22 Feb 2019

Rosales-Carreón J, García-Díaz C (2015) Exploring transitions towards sustainable construction: the case of near-zero energy buildings in the Netherlands. J Artif Soc Soc Simul 18: https://doi.org/10.18564/jasss.2625

Sachdeva S, Jordan J, Mazar N (2015) Green consumerism: moral motivations to a sustainable future. Curr Opin Psychol 6:60-65. https://doi.org/10.1016/j. copsyc.2015.03.029

Salganik MJ, Dodds PS, Watts DJ (2006) Experimental study of inequality and unpredictability in an artificial cultural market. Science 311:854-856. https:// doi.org/10.1126/science.1121066
Schultz PW, Nolan JM, Cialdini RB et al. (2007) The constructive, destructive, and reconstructive power of social norms. Psychol Sci 18:429-434. https://doi.org/ 10.1111/j.1467-9280.2007.01917.x

Silverblatt A (2004) Media as social institution. Am Behav Sci 48:35-41. https://doi. org $/ 10.1177 / 0002764204267249$

Singer P (2015) The most good you can do: how effective altruism is changing ideas about living ethically. Yale University Press, New Haven, London

Singer P (2009) Speciesism and moral status. Metaphilosophy 40:567-581. https:// doi.org/10.1111/j.1467-9973.2009.01608.x

Smith A, Reese J (2016) An empirical perspective on animal advocacy. Animal Sentience 1:12

Snow M (2015) Against charity. Jacobin

The Non-slaveholder (1847) Products of slave labor. Non-slaveholder 2(85-86):88

Tiefenbeck V, Staake T, Roth K, Sachs O (2013) For better or for worse? Empirical evidence of moral licensing in a behavioral energy conservation campaign. Energy Policy 57:160-171. https://doi.org/10.1016/j.enpol.2013.01.021

Tomasik B (2006) Does vegetarianism make a difference? https://reducingsuffering.org/does-vegetarianism-make-a-difference/. Accessed 22 Feb 2019

VRG (2019) Frequently Asked Questions. The Vegetarian Resource Group. https:// www.vrg.org/nutshell/faq.htm. Accessed 17 Jul 2019

Vuolo M, Staff J (2013) Parent and child cigarette use: a longitudinal, multigenerational study. Pediatrics 132:e568-e577. https://doi.org/10.1542/ peds.2013-0067

Wakslak CJ, Jost JT, Tyler TR, Chen ES (2007) Moral outrage mediates the dampening effect of system justification on support for redistributive social policies. Psychol Sci 18:267-274. https://doi.org/10.1111/j.1467-9280.2007. 01887.x

Witwicki K (2017) Social movement lessons from the British Antislavery Movement: focused on applications to the movement against animal farming. Sentience Institute

Witwicki K (2019) Global farmed \& factory farmed animals estimates. Sentience Institute. http://www.sentienceinstitute.org/global-animal-farming-estimates. Accessed 22 Feb 2019

Wyckoff J (2014) Toward Justice for Animals J Soc Phil 45(4):539-553

\section{Acknowledgements}

Thanks to Bob Fischer, Joshua Kissel, Brian Lowe, Kelly McNamara, Nathan Nobis, and Matti Wilks for extensive feedback on an early draft of this paper. Thanks to Jon Bockman, Lewis Bollard, Zach Freitas-Groff, and Kelly Witwicki for their contributions to the development of the institutional approach theory.

\section{Competing interests}

The author declares no competing interests.

\section{Additional information}

Correspondence and requests for materials should be addressed to J.R.

Reprints and permission information is available at http://www.nature.com/reprints

Publisher's note Springer Nature remains neutral with regard to jurisdictional claims in published maps and institutional affiliations.

Open Access This article is licensed under a Creative Commons Attribution 4.0 International License, which permits use, sharing, adaptation, distribution and reproduction in any medium or format, as long as you give appropriate credit to the original author(s) and the source, provide a link to the Creative Commons license, and indicate if changes were made. The images or other third party material in this article are included in the article's Creative Commons license, unless indicated otherwise in a credit line to the material. If material is not included in the article's Creative Commons license and your intended use is not permitted by statutory regulation or exceeds the permitted use, you will need to obtain permission directly from the copyright holder. To view a copy of this license, visit http://creativecommons.org/ licenses/by/4.0/

(C) The Author(s) 2020 